\title{
Morphogenesis on age categories of tillers in marandu palisadegrass
}

\author{
Adenilson José Paiva ${ }^{1}$, Sila Carneiro da Silva ${ }^{2 *}$, Lilian Elgalise Techio Pereira ${ }^{1}$, Fábio Olegário \\ Caminha ${ }^{1}$, Priscila de Mesquita Pereira ${ }^{1}$, Vitor Del'Álamo Guarda ${ }^{3}$ \\ ${ }^{1}$ USP/ESALQ - Programa de Pós-Graduação em Ciência Animal e Pastagens. \\ ${ }^{2}$ USP/ESALQ - Depto. de Zootecnia, C.P. 09 - 13418-900 - Piracicaba, SP - Brasil. \\ ${ }^{3}$ Embrapa Pesca e Aquicultura - Quadra 103 Sul, Av. JK,Cj. 01, Lt. 17, Palmas, TO - 77015-012, Brasil. \\ *Corresponding author <scdsilva@esalq.usp.br> \\ Edited by: Eros Artur Bohac Francisco/Daniel Scherer de Moura
}

\begin{abstract}
Knowledge regarding morphogenetic characteristics has contributed to the understanding of plant responses to variations in climatic conditions and management practices. However, the original framework has been developed for temperate grass species, and indicates no ontogenetic effect on the expression of morphogenetic traits. Similar information for tropical grass species is scarce, but not less important. This experiment aimed at evaluating the influence of tiller age on the morphogenetic characteristics of continuously stocked marandu palisadegrass swards maintained at $30 \mathrm{~cm}$ and fertilized with nitrogen $(\mathrm{N})$. Treatments corresponded to three nitrogen application rates $\left(150,300\right.$ and $450 \mathrm{~kg} \mathrm{ha}^{-1}$ of $\left.\mathrm{N}\right)$ plus the control (no fertilization) and were assigned to experimental units $\left(1,200 \mathrm{~m}^{2}\right.$ paddocks) according to a complete randomized block design, with four replications. The following response variables were measured during autumn/winter (Jun. to Jul. 2007) and summer (Feb. to Mar. 2008): leaf appearance rate (LAR), leaf elongation rate (LER) and the age profile of the tiller population. In general, LAR and LER were higher on young $(<2$ months old) relative to mature ( 2 to 4 months old) and old ( $>4$ months old) tillers during both autumn/winter and summer. During autumn/winter swards were mainly comprised of old tillers ( $>4$ months old), the opposite happening during summer, when they were mainly comprised of young tillers. Overall, there was no N effect within tiller age categories. Tiller age was an important factor interfering with the morphogenetic responses of marandu palisadegrass, indicating that there is an ontogenetic effect on plant morphogenesis that should be considered further in future studies of this nature.

Keywords: Brachiaria brizantha, tiller age, nitrogen, morphogenetic characteristics
\end{abstract}

\section{Introduction}

Morphogenesis is an important means of understanding plant growth and responses to climatic conditions and management, essential information for planning efficient and sustainable grazing strategies. Originally, the conceptual framework of Lemaire and Chapman (1996) was developed for temperate grass species and was comprised of three main morphogenetic characteristics: leaf appearance, leaf elongation and leaf lifespan. The same principles apply to tropical grass species, but an additional characteristic should be considered; stem elongation, since there is stem elongation during vegetative growth relative to temperate grass species (Da Silva and Nascimento Jr., 2007). Further, there are indications that the expression of the morphogenetic responses could be affected by tiller age, with rates of leaf appearance and elongation being higher for young $(<2$ months old) relative to old ( $>4$ months old) tillers (Carvalho et al., 2001), suggesting an ontogenetic effect not predicted in the original model of Lemaire and Chapman (1996).

Marandu palisadegrass (Brachiaria brizantha cv. Marandu) is one of the most important grass species in Brazil whose ideal range of targets for management under continuous stocking is 20 to $40 \mathrm{~cm}$, with high animal performance and weight gain per hectare at $30 \mathrm{~cm}$ at the expense of lower utilization efficiency of the produced herbage on swards managed tall (Da Silva, 2004). In this context, nitrogen $(\mathrm{N})$ could improve utilization efficiency of the ideal $30 \mathrm{~cm}$ target by increasing defoliation frequency of individual leaves and tillers (Lemaire et al., 2009). Further, it also results in higher turnover in tiller population (Caminha et al., 2010), altering the age profile of tillers that, in turn, could interfere with morphogenetic plant responses.

Against that background, this study aimed at evaluating the effect of tiller age categories on the morphogenetic responses of continuously stocked marandu palisadegrass maintained at $30 \mathrm{~cm}$ and fertilized with $\mathrm{N}$ rates.

\section{Materials and Methods}

The experiment was carried out in Piracicaba, state of São

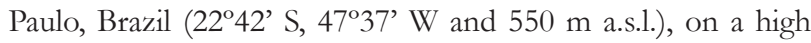
fertile Eutric Kandiudalf, from Jan. 2007 to Apr. 2008. Average soil chemical characteristics (van Raij et al., 1986) for the 0-20 cm layer were: $\mathrm{pH} 0.01 \mathrm{M} \mathrm{CaCl}_{2}: 5.0 ; \mathrm{OM}=41.6 \mathrm{~g} \mathrm{dm}^{-3}$; $\mathrm{P}$ (ionexchange resin extraction method) $=62.1 \mathrm{mg} \mathrm{dm}^{-3} ; \mathrm{Ca}=60.7$ $\mathrm{mmol}_{\mathrm{c}} \mathrm{dm}^{-3} ; \mathrm{Mg}=16.0 \mathrm{mmol}_{\mathrm{c}} \mathrm{dm}^{-3} ; \mathrm{K}=6.6 \mathrm{mmol}_{\mathrm{c}} \mathrm{dm}^{-3} ; \mathrm{H}+\mathrm{Al}$ $=44.3 \mathrm{mmol}_{\mathrm{c}} \mathrm{dm}^{-3}$; sum of bases $=99.0 \mathrm{mmol}_{\mathrm{c}} \mathrm{dm}^{-3}$; cation exchange capacity $=127.5 \mathrm{mmol}_{\mathrm{c}} \mathrm{dm}^{-3}$; base saturation $=65.5$ $\%$. The climate, according to Koppen, is the Cwa mesothermal humid subtropical of dry winter, with average temperatures lower than $18^{\circ} \mathrm{C}\left(12.5\right.$ to $\left.22.4{ }^{\circ} \mathrm{C}\right)$ in the coldest month and higher than $22{ }^{\circ} \mathrm{C}\left(19.8\right.$ to $\left.27.9^{\circ} \mathrm{C}\right)$ during summer. Climatic data during the experiment were collected in a Meteorological Station located at approximately $500 \mathrm{~m}$ from the experimental site (Figure 1).

The experimental area comprised four blocks containing four 1,200 $\mathrm{m}^{2}$ paddocks each and, prior to this study, it was used 
for a series of experiments on continuous stocking from 2001 to 2003 and another one on rotational stocking from 2004 to 2006 focusing on aspects of plant ecophysiology and grazing ecology. At the end of those experiments the area was kept under rotational stocking by beef cattle until Mar. 2006 and then staged at $10 \mathrm{~cm}$ in Apr. in preparation for the present experiment based on continuous stocking management. Management target was a sward surface height of $30 \mathrm{~cm}$, a condition that, based on the results of the previous series of experiments under continuous stocking (swards maintained at 10, 20,30 and $40 \mathrm{~cm}$ ), resulted in high herbage accumulation, high animal performance and productivity, but low utilization efficiency of the produced herbage (Da Silva and Nascimento Jr., 2007).

Monitoring of sward surface height started soon after staging and it was performed in a weekly basis until swards had reached around $20 \mathrm{~cm}$, when the frequency of monitoring increased to twice a week until the end of the experiment. A total of 100 readings per paddock was recorded using a sward stick (Barthram, 1985). These were taken along four transect lines arranged in a zigzag format (25 points per transect). A tolerance range of $\pm 10 \%$ was established for variations around the target $(27$ to $33 \mathrm{~cm}$ ), and as the lower limit of the range was reached, animals started to be placed on paddocks, from Oct. 2006 onwards. Animals were added or removed from paddocks according to the need to maintain sward target relatively stable and around $30 \mathrm{~cm}$. Grazing was carried out by Nelore (Bos taurus indicus) and Canchim (3/8 Charolais - Bos taurus taurus $-\times 5 / 8$ Zebu Bos taurus indicus - crossbred) heifers with an average initial body weight of 250 to $280 \mathrm{~kg}$. Variation in sward surface height throughout the experiment remained within the prespecified range $(30 \mathrm{~cm} \pm 10 \%)$, with an average of $29.7 \mathrm{~cm}$ $( \pm 0.67)$ varying from 27.8 to $31.0 \mathrm{~cm}$ (Figure 2). Stocking rate used to control grazing and maintain swards on target varied from 0.3 to 5.6 animal units $\mathrm{ha}^{-1}$ (1 $\mathrm{AU}=$ one adult bovine weighing $450 \mathrm{~kg}$ ) throughout the year.

Treatments corresponded to the application of 150, 300 and $450 \mathrm{~kg} \mathrm{ha}^{-1}$ of $\mathrm{N}$ plus the control (no fertilization) using pure ammonium nitrate. The total dose was applied in four equal dressings throughout the year in the following dates: Year $1-19$ Dec. 2006; 16 Jan. 2007; 23 Feb. 2007 and 23 Mar. 2007; Year 2 - 20 Dec. 2007; 17 Jan. 2008; 14 Feb. 2008 and 13 Mar. 2008.

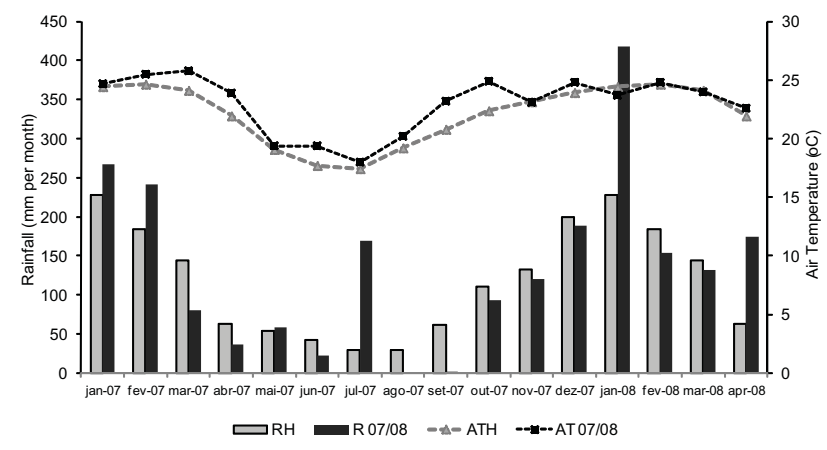

Figure 1 - Monthly (Jan. 2007 to Apr. 2008) and historical (H) (1917 to 2007) means of rainfall (R 07/08 and RH, respectively) and air temperature (AT 07/08 and ATH, respectively) for the experimental site.
The experimental design was a randomized complete block, with four replications. Evaluations were initiated only after all 16 paddocks (experimental units) had reached the sward target of 30 $\mathrm{cm}$ and were being continuously stocked by cattle, a condition that only happened from Dec. 2006 onwards. For that reason, the experimental period started only in Jan. 2007 and finished in Apr. 2008, comprising two entire consecutive pasture growing seasons (2006/2007 and 2007/2008).

Measurements of the morphogenetic characteristics of tiller age categories were performed during autumn/winter (07 Jun. to 30 Jul. 2007) and summer (22 Feb. to 19 Mar. 2008), periods of slow and fast growth of forage plants, respectively, using marked tillers monitored every four weeks in a concomitant experiment in the same experimental area dealing with demographic patterns of tillering (Caminha et al., 2010). All tillers within three 30-cm diameter PVC rings per experimental unit $\left(1,200 \mathrm{~m}^{2}\right.$ paddocks $)$ were tagged at the beginning of the experiment and new tillers tagged and living and dead ones counted every four weeks. Based on dates of appearance, tillers were divided into three age categories, as described by Carvalho et al. (2001): (i) old tillers: $\geq 4$ months; (ii) mature tillers: 2 to 4 months; and (iii) young tillers: $\leq 2$ months. Thus, for the winter measurements tillers comprising the categories were: (i) old tillers - tillers that had appeared in Jan. and Feb. 2007; (ii) mature tillers - tillers that had appeared in Mar. and Apr. 2007; (iii) young tillers - tillers that had appeared in May and Jun. 2007. For the summer measurements, tiller categories corresponded to: (i) old tillers - tillers that had appeared in or before Oct. 2007; (ii) mature tillers - tillers that had appeared in Nov. and Dec. 2007; (iii) young tillers - tillers that had appeared in Jan. and Feb. 2008.

During autumn/winter and summer six tillers for each age category per PVC ring were identified, totaling 72 tillers for each age category per treatment. These tillers were marked with a plastic ring and monitored once a week during autumn/winter and twice a week during summer. Marked tillers were classified as basal or aerial, intact or defoliated. Additionally, leaves were classified as intact or defoliated and had their lamina length measured. On expanded leaves, length was measured from the tip of the leaf to its ligule. On expanding leaves, the procedure was the same except that it used the ligule of the last expanded leaf as reference. Data were then used to calculate (i) leaf ap-

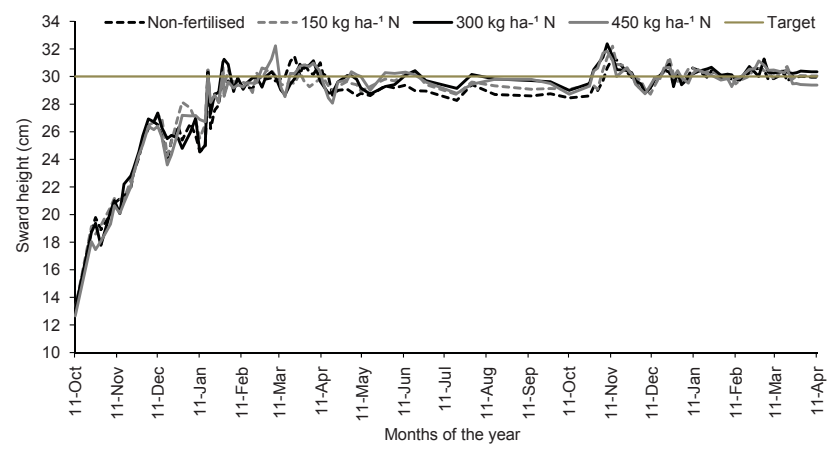

Figure 2 - Average sward height of continuously stocked marandu palisadegrass from Oct. 2006 to Apr. 2008. 
pearance rate (LAR), calculated as the number of new leaves produced per tiller divided by the number of days of each assessment period, and (ii) leaf elongation rate (LER), calculated as the cumulative increase in leaf length divided by the number of days of each assessment period.

Age profile of tiller population was calculated as the proportion of tillers in each age category in a monthly basis from Jun. 2007, since it was only then that there were marked tillers comprising all tiller age categories (old, mature and young). Data regarding the morphogenetic characteristics of tillers for each season (autumn/winter and summer) were subjected separately to analysis of variance using the PROC GLM (linear model) of SAS® (Statistical Analysis System) version 9.0 for Windows ${ }^{\circledR}$. When appropriate, treatment means were estimated using the "LSMEANS" statement and comparisons made with "PDIFF" based on a Student test and a $5 \%$ significance level. Data related to the proportion of tiller age categories in tiller population were analyzed using the PROC MIXED (mixed model) of the same statistical package. The choice of the covariance matrix was made using the Akaike Information Criterion (AIC) (Wolfinger, 1993) (the smaller the best), and analysis performed considering nitrogen fertilization, tiller age, month of the year and their interactions as fixed effects and blocks as random effect (Littell et al., 1996). When appropriate, treatment means were calculated using the "LSMEANS" statement, and comparisons made with "PDIFF" based on a Student test and a $5 \%$ significance level.

\section{Results}

In autumn/winter rates of leaf appearance (LAR) varied with tiller age category $(p \leq 0.001)$ and $\mathrm{N}$ fertilization $(p=$ $0.0004)$. Old tillers had lower LAR than mature and young tillers (Figure 3), and highest values were recorded on swards fertilized with $450 \mathrm{~kg} \mathrm{ha}^{-1}$ of $\mathrm{N}$ (Figure 4). Leaf elongation rate (LER) was affected by nitrogen fertilization $(p \leq 0.0001)$, tiller age category $(p \leq 0.0001)$ and the nitrogen fertilization $\times$ tiller age category interaction $(p=0.0413)$. Overall, highest values of LER were recorded for young and mature tillers, except on swards fertilized with $450 \mathrm{~kg} \mathrm{ha}^{-1}$ of $\mathrm{N}$, a condition that resulted in higher LER for young relative to mature tillers (Figure 5). For

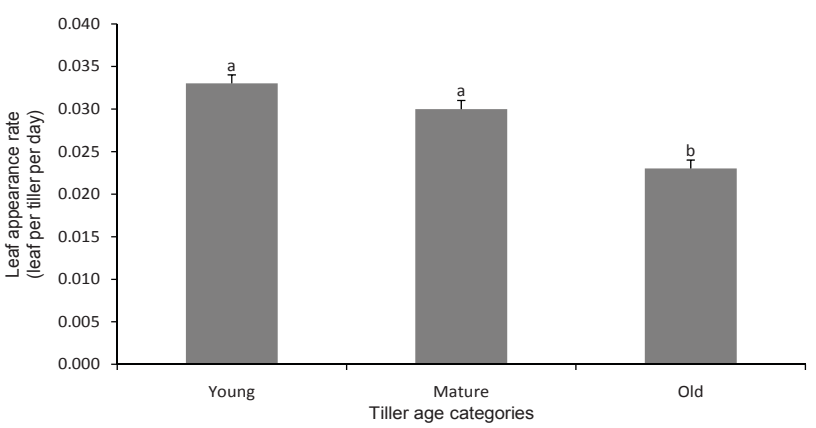

Figure 3 - Leaf appearance rate according to tiller age categories on continuously stocked marandu palisadegrass swards during autumn/winter. Means followed by the same lower case letter are not different (Student test, $p>0.05)$. young tillers, LER increased as $\mathrm{N}$ application rate increased, which did not happen to mature and old tillers. In summer, rates of leaf appearance $(p \leq 0.0001)$ and elongation $(p \leq 0.0001)$ varied only with tiller age category, with highest values recorded for young and lowest values recorded of old tillers (Table 1).

The profile of tiller age in tiller population varied with tiller age category $(p \leq 0.0001)$ and with the nitrogen fertilization $\times$ tiller age category $(p \leq 0.0001)$, tiller age category $\times$ month of the year $(p \leq 0.0001)$ and $\mathrm{N}$ fertilization $\times$ tiller age category

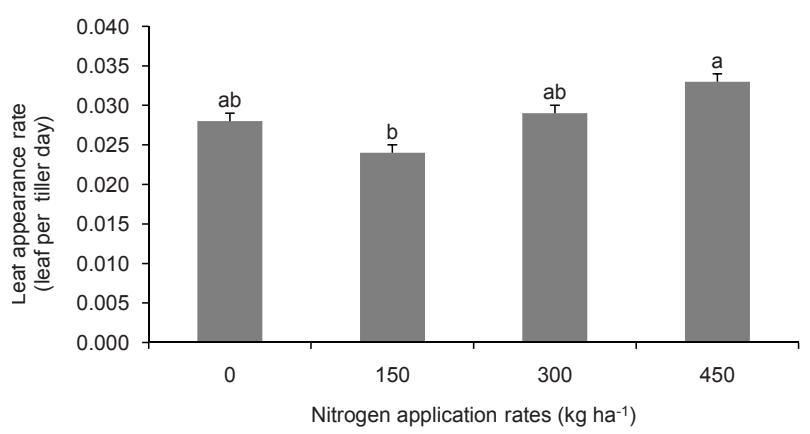

Figure 4 - Leaf appearance rate on continuously stocked marandu palisadegrass swards fertilized with nitrogen rates during autumn/winter. Means followed by the same lower case letter are not different (Student test, $p>0.05$ ).

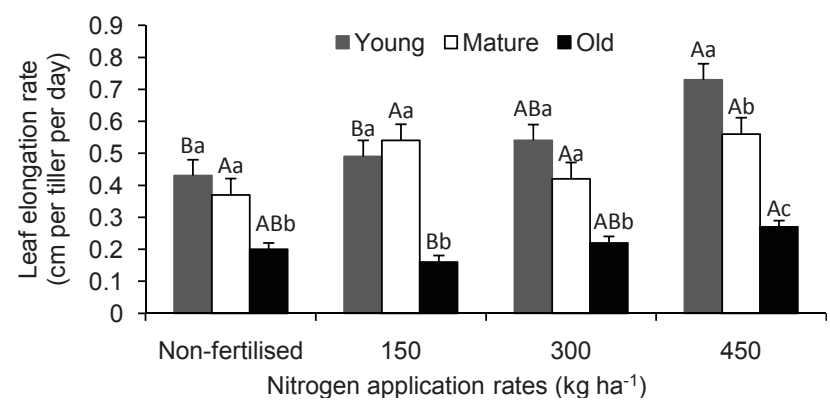

Figure 5 - Leaf elongation rate of tiller age categories on contin ously stocked marandu palisadegrass swards fertilized with nitrogen rates during autumn/winter. (Upper case letters compare nitrogen rates within tiller age categories; Lower case letters compare tiller age categories within nitrogen rates). Means fo lowed by the same letter are not different (Student test, $p>0.05$ ).

Table 1 - Leaf appearance rate (LAR) and leaf elongation rate (LER) of tiller age categories on continuously stocked marandu palisadegrass swards during summer.

\begin{tabular}{lcc}
\hline Tiller age & $\begin{array}{c}\text { LAR } \\
\text { (leaf per tillerper } \\
\text { day) }\end{array}$ & $\begin{array}{c}\text { LER } \\
\text { (cm per tiller per } \\
\text { day) }\end{array}$ \\
\hline Young & $0.097 \mathrm{a}$ & $1.39 \mathrm{a}$ \\
Mature & $0.064 \mathrm{~b}$ & $0.78 \mathrm{~b}$ \\
Old & $0.048 \mathrm{c}$ & $0.45 \mathrm{c}$ \\
SEM $^{*}$ & 0.003 & 0.06 \\
\hline
\end{tabular}

Means followed by the same lower case letter in columns are not different (Student test, $p>0.05)$. ${ }^{*}$ SEM - standard error of the mean. 
$\times$ month of the year $(p \leq 0.0001)$ interactions. In general, tiller age profile showed a similar pattern of variation for the $\mathrm{N}$ application rates studied from Jun. 2007 to Feb. 2008. From Jul. to Oct. 2007, swards were mainly formed by old tillers with larger differences between the proportion of old and mature/ young tillers on swards fertilized with 300 and $450 \mathrm{~kg} \mathrm{ha}^{-1}$ of $\mathrm{N}$ (Figures 6, 7, 8 and 9). From Oct. onwards the proportion of old tillers started to decrease and of young tillers to increase, a pattern that became more evident on swards fertilized with higher rates of $\mathrm{N}$ application and resulted in larger proportions of young relative to old tillers in Feb. 2008 (46, 57, 63 and 73 $\%$ of young and $22,16,13$ and $10 \%$ of old tillers on swards fertilized with $0,150,300$ and $450 \mathrm{~kg} \mathrm{ha}^{-1}$ of $\mathrm{N}$, respectively). The proportion of mature tillers on swards also increased, but that happened only from Dec. 2007 onwards.

\section{Discussion}

A marked effect of $\mathrm{N}$ fertilization is to promote a high turnover in tiller population, since it increases tiller death and

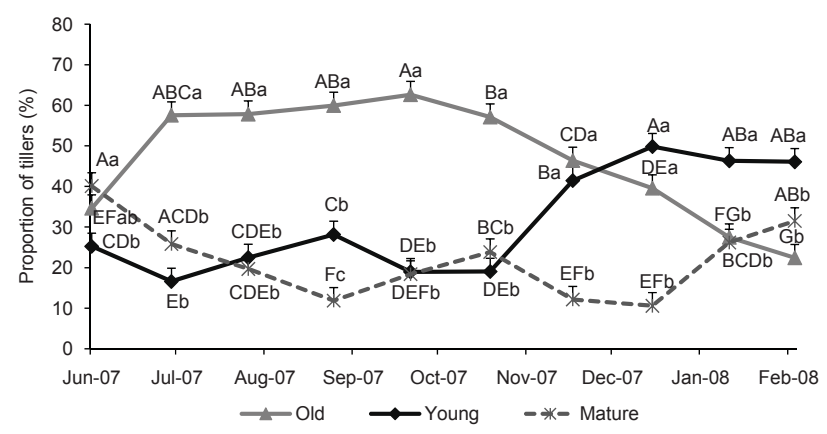

Figure 6 - Age profile of tiller population in continuously stocked marandu palisadegrass swards maintained at $30 \mathrm{~cm}$ with no nitrogen fertiliser application from Jun. 2007 to Feb. 2008. (Lower case letters compare means within months of the year; Upper case letters compare means within each age category). Means followed by the same letter are not different (Student test, $p>0.05$ ).

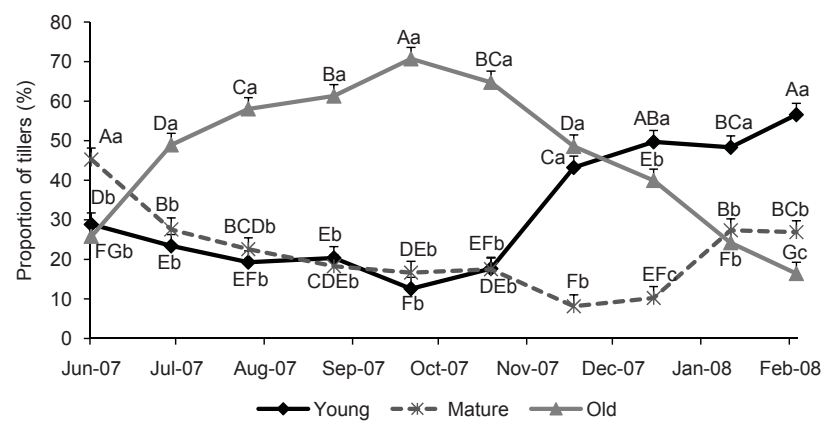

Figure 7 - Age profile of tiller population in continuously stocked marandu palisadegrass swards maintained at $30 \mathrm{~cm}$ and fertilized with $150 \mathrm{~kg} \mathrm{ha}^{-1}$ of $\mathrm{N}$ from Jun. 2007 to Feb. 2008. Lower case letters compare means within months of the year; Upper case letters compare means within each age category. Means followed by the same letter are not different (Student test, $p>0.05$ ). appearance (Cruz and Boval, 2000; Caminha et al., 2010). From Jun. to Oct. 2007, period of low temperatures and rainfall (Figure 1), turnover in tiller population was slow, causing old tillers to be the predominant tiller age category relative to mature and young tillers. Under those conditions, it is usual to have low appearance and high survival of tillers (Murphy and Briske, 1992). Such a pattern of response indicates that under limiting environmental conditions to plant growth plants rely on resource conservation strategies as a means of ensuring persistence and production, which are usually associated with increased leaf and tiller life span (Navas et al., 2003; Giacomini et al., 2009). From Oct. onwards, with increasing rainfall, temperature and light availability, swards initiated an intense tillering process that resulted in high turnover in tiller population and swards comprised mainly of young than mature and old tillers (Figures 6, 7, 8 and 9). Such pattern of response was similar to all $\mathrm{N}$ application rates studied, the only difference being the magnitude of changes, with higher turnover on swards fertilized with 300 and $450 \mathrm{~kg} \mathrm{ha}^{-1}$ of $\mathrm{N}$ relative to those non-fertilized or fertilized with $150 \mathrm{~kg} \mathrm{ha}^{-1}$ of $\mathrm{N}$. There are evidences generated

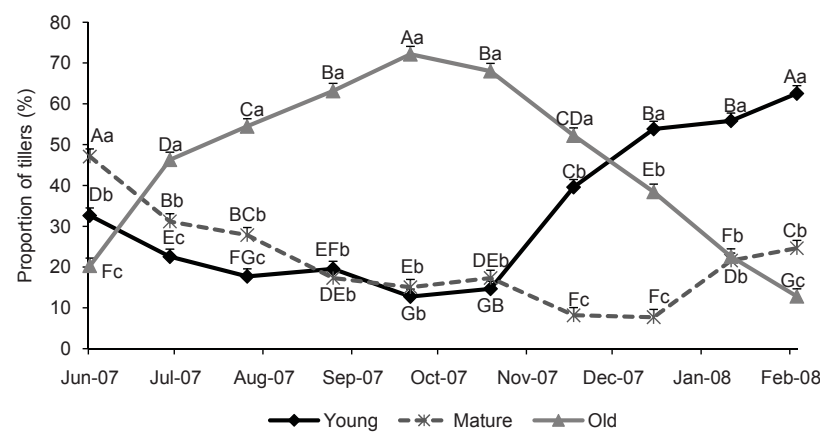

Figure 8 - Age profile of tiller population in continuously stocked marandu palisadegrass swards maintained at $30 \mathrm{~cm}$ and fertilized with $300 \mathrm{~kg} \mathrm{ha}^{-1}$ of $\mathrm{N}$ from Jun. 2007 to Feb. 2008. Lower case letters compare means within months of the year; Upper case letters compare means within each age category. Means followed by the same letter are not different (Student test, $p>0.05$ ).

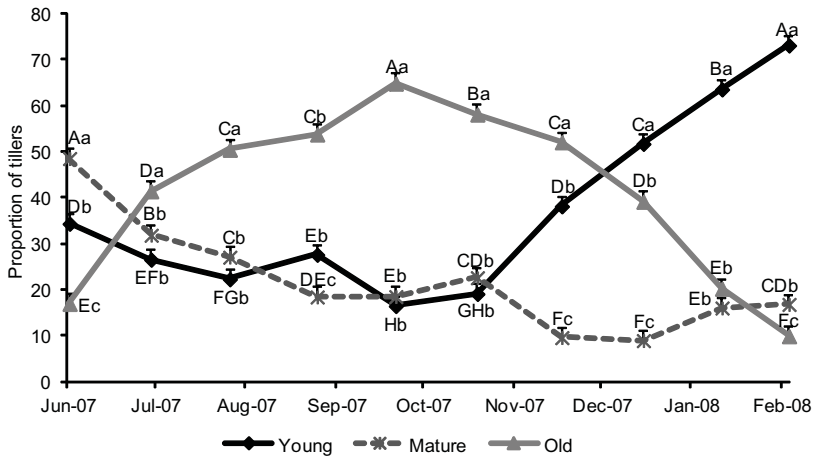

Figure 9 - Age profile of tiller population in continuously stocked marandu palisadegrass swards maintained at $30 \mathrm{~cm}$ and fertilized with $450 \mathrm{~kg} \mathrm{ha}^{-1}$ of $\mathrm{N}$ from Jun. 2007 to Feb. 2008. Lower case letters compare means within months of the year; Upper case letters compare means within each age category. Means followed by the same letter are not different (Student test, $p>0.05$ ). 
with Panicum maximum cv. Mombaça and Tanzânia indicating that young tillers have higher growth rates (leaf appearance and elongation rates) than old tillers (Carvalho et al., 2001), which is corroborated by the results of this experiment with Brachiaria brizantha cv. Marandu. Leaf appearance rate (LAR) varied with tiller age category, being smaller on old relative to mature and young tillers (Figures 3 and 4). During summer, differences between tiller age categories were more evident, since there were differences among all age categories (Table 1). LAR on mature and old tiller was 34 and $51 \%$ lower than on young tillers, respectively. During autumn/winter, LAR was affected by both tiller age category (Figure 3) and $\mathrm{N}$ fertilization (Figure 4), with differences between age categories being recorded only between old and mature/young tillers. The pattern of difference in plant response during summer and autumn/winter was probably due to the high sensitivity of LAR to changes in air temperature around the growing point region (Peacock, 1975). Variations in LAR regarding the $\mathrm{N}$ fertilization did not follow a defined pattern of response, since the highest values were recorded on swards fertilized with 450 $\mathrm{kg} \mathrm{ha}{ }^{-1}$ of $\mathrm{N}$, which differed only from those recorded on swards fertilized with $150 \mathrm{~kg} \mathrm{ha}^{-1}$ of $\mathrm{N}$. Variations in LAR on swards fertilized with $\mathrm{N}$ are probably related with the direct effect $\mathrm{N}$ has on the cell flux within the meristematic zone of leaves (MacAdam et al., 1989).

The decrease in LAR with the aging process of tillers may be a result of two factors. One could be related to the increase in pseudostem length as tillers aged (varied from 7 to $18 \mathrm{~cm}$ in autumn/winter and from 11 to $18 \mathrm{~cm}$ in summer for young and old tillers, respectively). According to Lemaire and Chapman (1996), with longer pseudostem there is a delay in the appearance of new leaves, condition that results in longer intervals between the appearance of two successive leaves (Cruz and Boval, 2000). However, this result alone does not explain the decrease in LAR with aging of tillers, because old tillers had shorter leaf lamina than young tillers $(11.9$ and $15.7 \mathrm{~cm} \pm 1.22$ for old and young tillers, respectively) a condition that is associated with stem elongation and, as a consequence, reduction in pseudostem length (Hodgson, 1990). In this context, a second factor that could be causing the decrease in LAR with aging of tillers would be the reduction in photosynthetic efficiency of old leaves and tillers. The decrease in photosynthetic efficiency with the aging process of tillers could be related to anatomical and physiological changes in leaves, but evidences on that are still scarce (Peri et al., 2003).

Similar to LAR, the rate of leaf elongation (LER) was also influenced by tiller age, probably through changes in photosynthetic efficiency of different age categories (Peri et al., 2003), since old tillers had lower LER than young tillers. During autumn/winter, LER was additionally influenced by $\mathrm{N}$ fertilization (Figure 5), a result in line with reports found in the literature regarding morphogenetic responses of plants to that nutrient (Gastal and Nelson, 1994; Lemaire and Chapman, 1996; Alexandrino et al., 2004). Further, tiller age categories had different intensities of response to higher rates of $\mathrm{N}$ application, with young tillers being more responsive than old tillers. Within each age category, only young tillers showed increase in
LER in response to high rates of $\mathrm{N}$ application, even during a time of the year characterized by low temperatures and rainfall. The effect of tiller age on LER became more evident in summer (Table 1), since LER did not vary with $\mathrm{N}$ fertilization in spite of the large sensitivity of that morphogenetic response to nitrogen supply (Lemaire and Chapman, 1996; Cruz and Boval, 2000). Overall, there was no effect of $\mathrm{N}$ fertilization within tiller age categories, probably because there was no $\mathrm{N}$ deficiency even in the non-fertilized swards $\left(12.8,13.9,18.322 .6 \mathrm{~g} \mathrm{~kg}^{-1}\right.$ \pm 2.14 for $0,150,300$ and $450 \mathrm{~kg} \mathrm{ha}^{-1}$ of $\mathrm{N}$ relative to the minimum concentration of $8.5 \mathrm{~g} \mathrm{~kg}^{-1}$ - Abreu and Monteiro, (1999), consequence of the high organic matter content of the soil $\left(41.6 \mathrm{~g} \mathrm{dm}^{-3}\right)$. The fact indicates that tiller age may be the main factor determining the morphogenetic responses of marandu palisadegrass and highlights a strong ontogenetic effect related to tiller demography and patterns of tiller dynamics in the sward. This is a new development in plant morphogenesis and indicates an additional level of complexity to the study of tropical grass species compared to temperate grasses. However, results must be considered carefully because age categories were defined in chronological terms (months) and not in physiologi$\mathrm{cal} /$ phenological terms, a condition that should be considered in future experiments of this nature.

\section{References}

Abreu, J.B.R.; Monteiro, F.A. 1999. Marandu grass yield and nutrition in relation to growth stage and nitrogen fertilization. Boletim de Indústria Animal 56: 137-146 (in Portuguese, with abstract in English).

Alexandrino, E.; Nascimento Júnior, D.; Mosquim, P.R.; Regazzi, A.J.; Rocha F.C. 2004. Morphogenesis and structural characteristics of regrowth of Brachiaria brizantha cv. marandu assigned to three nitrogen levels. Revista Brasileira de Zootecnia 33: 1372-1379 (in Portuguese, with abstract in English).

Barthram, G.T. 1985. Experimental techniques: the HFRO sward stick. p. 29-30. In: Hill Farming Research Organisation 1985. Biennial Report, HFRO, Midlothian, UK.

Cruz, P.; Boval, M. 2000. Effect of nitrogen on some morphogenetic traits of temperate and tropical perennial forage grasses. p. 151-168. In: Lemaire, G.; Hodgson, J.; Moraes, A. (ed.). Grassland ecophysiology and grazing ecology. Wallingford: CABI, UK.

Caminha, F.O.; Da Silva, S.C.; Paiva, A.J.; Pereira, L.E.T.; Mesquita, P.; Guarda, V.D. 2010. Stability of tiller population of continuously stocked marandu palisadegrass fertilized with nitrogen. Pesquisa Agropecuária Brasileira 45: 213-220.

Carvalho, D.D.; Matthew, C.; Hodgson, J. 2001. Effect of aging in tillers of Panicum maximum on leaf elongation rate. In: Proceedings of the International Grassland Congress. São Pedro, SP, Brazil. p. 41-42.

Da Silva, S.C. 2004. Understanding the dynamics of herbage accumulation in tropical grass species: the basis for planning efficient grazing management practices. In: Proceedings of the Symposium of Grassland Ecophysiology and Grazing Ecology, 2. UFPR, Curitiba, PR, Brazil. p. 1-46.

Da Silva, S.C.; Nascimento Júnior, D. 2007. Advances in research on tropical forage plants in pastures: physical and physiological characteristics and grazing management. Revista Brasileira de Zootecnia 36: 121-138 (in Portuguese, with abstract in English).

Gastal, F.; Nelson, C.J. 1994. Nitrogen use within the growing leaf blade of tall fescue. Plant Physiology 105: 191-197.

Giacomini, A.A.; Da Silva, S.C.; Sarmento, D.O.L.; Zeferino, C.V.; Souza Júnior, S.J.; Trindade, J.K.; Guarda, Vítor, D.G.; Nascimento Júnior, D. 2009. Growth of marandu palisadegrass subjected to strategies of intermittent stocking. Scientia Agricola 66: 733-741. 
Hodgson, J. 1990. Grazing Management-Science into Practice, Longman Scientific and Technical, Essex, UK. 203 p.

Lemaire, G.; Da Silva, S.C.; Agnusdei, M.; Wade, M.; Hodgson, J. 2009. Interactions between leaf lifespan and defoliation frequency in temperate and tropical pastures: a review. Grass and Forage Science 64: 341-353.

Lemaire, G.; Chapman, D. 1996. Tissue fluxes in grazing plant communities. p. 3-36. In: Hodgson, J.; Illius, A.W., eds. The ecology and management of grazing systems. CABI, Wallingford, UK.

Littell, R.C.; Milliken, G.A.; Stroup, W.W.; Wolfinger, R.D. 1996. SAS System for Mixed Models. SAS Institute, Cary, NC, USA.

MacAdam, J.W.; Volenec, J.J.; Nelson, C.J. 1989. Effects of nitrogen on mesophyll cell division and epidermal cell elongation in tall fescue leaf blades. Plant Physiology 89: 549-556.

Murphy, J.S.; Briske, D.D. 1992. Regulation of tillering by apical dominance: chronology, interpretive value, and current perspectives. Journal of Range Management 45: 419-429.

Navas, M.L.; Ducout B.D.; Roumet C.; Richarte J.; Garnier J.; Garnier E. 2003. Leaf life span, dynamics and construction cost of species from Mediterranean old-fields differing in successional status. New Phytologist 159: 213-228.
Peacock, J.M. 1975. Temperature and leaf growth in Lolium perene. The thermal microclimate: its measurement and relation to plant growth. Journal of Applied Ecology 12: 115-123.

Peri, P.L.; Moot, D.J.; McNeil, D.L.; Lucas, R.J. 2003. Modelling net photosynthetic rate of field-grown cocksfoot leaves to account for regrowth duration. New Zealand Journal of Agricultural Research 46: 105-115.

Van Raij, B.; Quaggio, J.A.; Silva, N.M. 1986. Extraction of phosphorus, potassium, calcium and magnesium from soils by an ion-exchange resin procedure. Communications in Soil Science and Plant Analysis 17: 547-566.

Wolfinger, R.D. 1993. Covariance structure selection in general mixed models. Communications in Statistics Simulation and Computation 22: 1079-1106.

Received July 22, 2010

Accepted May 31, 2011 